\title{
Hypothyroidism and Ayurveda
}

\author{
Dr Avinash Shankar ${ }^{1}$, Dr Amresh Shankar², Dr Anuradha Shankar ${ }^{3}$ \\ ${ }^{l} M B B S(M G I M S) ; M D($ Internal Medicine);DNB(E\&M); PhD, Post graduate in Edocrinology \& Metabolism \\ (AIIMS-Delhi), Chairman, National Institute of Health \& Research, Warisaliganj (Nawada), 805130, Bihar, \\ India \\ ${ }^{2}$ BAMS (BRABU); MBA (HA), Bihar state Health Services, Govt of Bihar, Patna \\ ${ }^{3} B A M S(B R A B U)$, Director, Centre For Indigenous Medicine \& Research, National Institute, Of Health \& \\ Research, Warisaliganj (Nawada),805130,Bihar, India
}

*Corresponding Author: Avinash Shankar, MBBS(MGIMS);MD(Internal Medicine); DNB (E\&M); PhD, Post graduate in Edocrinology \& Metabolism (AIIMS-Delhi), Chairman, National Institute of Health \& Research, Warisaliganj (Nawada), 805130, Bihar, India

\begin{abstract}
Clinical manifestations suggestive of myxedema in women opting tube ligation and hysterectomy Or both where TSH level remain below 5.5 but $>0.5$ remain untreated and patients of myxedema even taking levo thyroxin supplementation fails to respond properly need bio regulation of thyroid function but remain deprived of ionic calcium, regulated by Calcitonin secretion of Parafollicular cells of thyroid gland,thus in this study both fresh and old cases presenting with agonizing feature, taking trial herbal composite Thyro Reg 1 Cap daily with Calcium gluconate every $15^{\text {th }}$ day intravenous slow and Vitamin D3 $60 \mathrm{~K}$ every week shows grade I recovery in majority cases against non of control group, suggest thyro bioregulation and ensure improved quality of life.
\end{abstract}

Keywords: Tube ligation, hysterectomy, TSH, bioregulation, Levo thyroxin, Parafollicular cells, Cholecalciferol, Ionic calcium

\section{INTRODUCTION}

Hypothyroidism progressively increasing globally in spite of WHO measure to supplement common dietary salt with iodine and in India too, there is a significant burden hypothyroidism and estimates about 42 million people in India suffer from thyroid diseases ${ }^{1,2}$. Primary hypothyroidism is a common medical problem occurring in approximately 1 to $3 \%$ of the total population, with an annual incidence rate of 1 to 2 in 1000, in females; and 2 in 10000 in males ${ }^{3,4,5}$. Increasing incidence is thought to be due to life style changes, dietary composite constituting growth hormone, pesticide, chemical and synchronized in women due to early cessation of child bearing either by tube ligation or hysterectomy.

Genesis of non dietary nitrogen in dietary constituent and chemicals which suppresses enzymes regulating body metabolism, alters iodination of Tyrosin, in addition also affect $\mathrm{C}$ cells of thyroid gland and suppress Calcium metabolism and decline ionic calcium level, accumulation of free radicals and present with presentation due to deficiency of both Thyroxin and Calcitonin (causing ionic Calcium deficiency)

Presentations suggestive of Myxedema is increasing progressively in women who opted tube ligation or hysterectomy or both and common are ${ }^{6}$

Heaviness in the body, exertional dyspnoea, leg cramps, lethargy, palpitation, constipation and menstrual abnormality (except in hysterectomy cases) whose investigation for thyroid profile shows TSH level within the range of euthyroid state though serum calcium and vitamin D3 levels are markedly low ${ }^{7}$.

As in these cases levo thyroxin supplementation seems risky but failure of conservative management fails to alleviate clinical presentation ${ }^{8,9,10,11}$, in addition patients taking even progressively increasing dose of Levothyroxin supplementation fails to improve the clinical presentation, though TSH level gets decreased ,thus in these cases a herbal composite been evaluated for its clinical efficacy in alleviation of clinical presentation and safety profile. 


\section{MATERiAL AND Methods}

Patients attending Centre For Research In Endocrinology \& Metabolism of National Institute of Health \& Research, Warisaliganj (Nawada) Bihar India during January 2010 -January 2014 with manifestations suggestive of hypothyroidism been selected for evaluation of clinical efficacy and safety profile of the herbal composite.

In this study patients of hypothyroidism consuming Levo thyroxin not responding to even higher doses or nor producing satisfactory outcome been also selected for evaluation, cases suspective of malignancy were excluded from the study.

All selected patients were interrogated thoroughly for the history of presentation ,treatment taken, response of therapy, tbe ligation or hysterectomy or both , examined clinically to adjudge body weight, blood pressure ,cardiac status, renal function and investigated for basic blood sugar, thyroid profile, hepatic and renal profile and hematology to adjudge the clinical efficacy and safety profile of the drug.

Selected patients were classified in to two equal groups constituting equal number of patients and are clinically graded as -

$\begin{array}{cc}\text { Grade I : } & \text { Patients with clinical presentation of hypothyroidism with TSH between 1-5.5 } \\ \text { Grade II: } & \text { Patients with clinical presentation suggestive of hypothyroidism with progressive rise in } \\ \text { TSH even with Levo thyroxin supplementation }\end{array}$

Grade III: $\quad$ Patients with increasing clinical presentation of hypothyroidism without any surge in TSH

Both group of patients were given -

Inj Calcium Gluconate supplementation intravenous every $15^{\text {th }}$ day very slow (Till patient remain normotensive)

Cap Cholecalciferol (Vitamin D) $60 \mathrm{~K}$ supplementation every week.

In addition

Group A: Trial drug (THYRO Reg) 1 cap daily after breakfast

Group B: Placebo

Each Cap of Thyro Reg 500mg constitutes active ingredients of -

\begin{tabular}{|lcll|}
\hline Bouhinia variegata(Kachnar) & $120 \mathrm{mg}$ & Zingiber officinale (Shunthi) & $12 \mathrm{mg}$ \\
Piper nigrum (Kali mirch) & $12 \mathrm{mg}$ & Piper longum (Pipali) & $12 \mathrm{mg}$ \\
Terminalia chebula (Haritki) & $24 \mathrm{mg}$ & Terminalia bellerica(Bibhitika) & $24 \mathrm{mg}$ \\
Embelica officinalis(Amliki) & $24 \mathrm{mg}$ & Crataeva nurvala (Varuna) & $12 \mathrm{mg}$ \\
Cinnamomum tamala (Tejpata) & $3 \mathrm{mg}$ & & \\
Elletaria cardemomum (Ilaychi) & $3 \mathrm{mg}$ Cinnamomum zeylanicum (Dalchini) 3mg Commiphora \\
mukul (Gugglu) & $150 \mathrm{mg}$ & \\
Herpestis monnieri (Brahmi) & $100 \mathrm{mg}$ &
\end{tabular}

In addition patients taking levo thyroxin of either group been been continued with continuing dose with an instruction to consume Levothyroxin at fixed time early in the morning without any prior water intake with dietary precaution to abstain from raw radish, onion, garlic, zinger ,mustard leaf, vegitables of cruciferae family and poultry products and products suspicious of hormone adjunction .

All patients been given a follow up card to enter the following and report any urgency to the Program manager or consult the clinician.

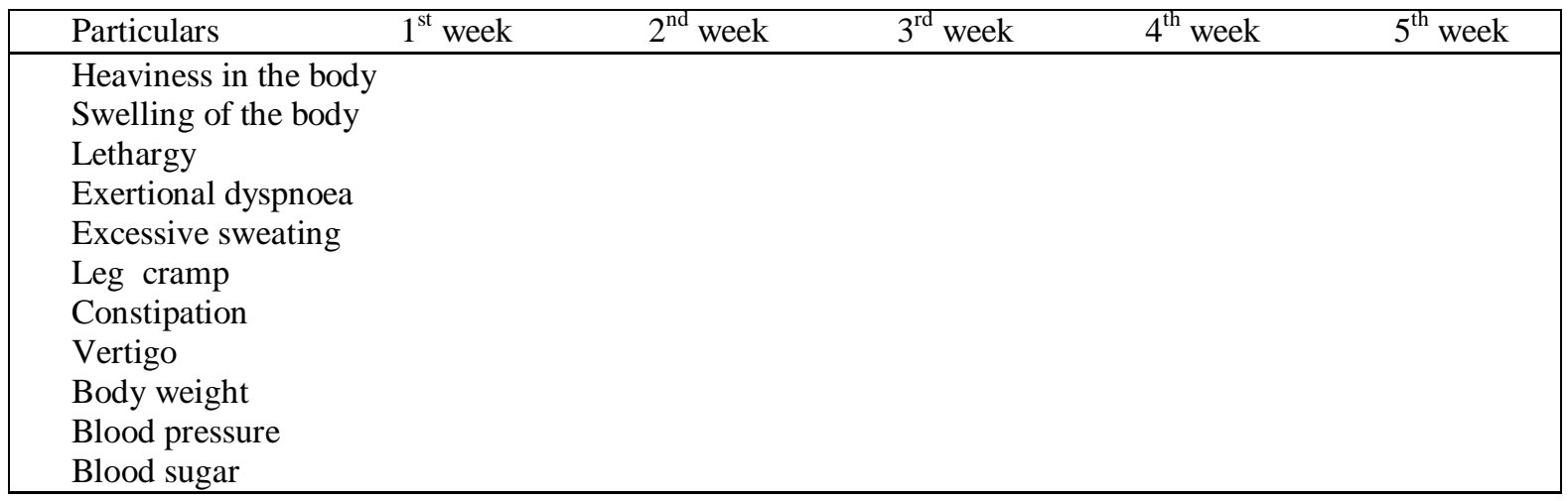


Thyroid profile was repeated every 4 months till $1^{\text {st }}$ year then every 6 month for 3 years. In addition Hepato renal and hematological status was also recorded every years to adjudge therapeutic effect and safety profile.

Clinical efficacy was graded as -

Grade I: Complete alleviation of presenting features with normal IBW without any Levo thyroxin adjunction or drug adversity or symptom exacerbation ..

Grade II Complete alleviation of presentation with IBW and decline in continuing Levothyroxin dose without any adversity

GradeIII Complete alleviation of clinical presentation with IBW without any lowering in continuing Levo thyroxin dose and drug adversity .

\section{OBSERVATION}

Among the selected female patients 07 cases were of age $<25$ years while 173 were of age $>45$ years but majority 183 were of age group 35-40 years (T-1)

Out of all $64.2 \%$ were with tube ligation and $35.8 \%$ with hysterectomy (pie diagram)

Commonest presentation among the patients was heaviness in the body, lethargy, exertional dyspnoea, vertigo, constipation and abnormal menses (in tube ligated female) (T-2)

Out of all $62(8.4 \%)$ were suffering since $<1 \mathrm{yr}$ while $17(3.7 \%)$ were from $>10$ years, majority patients $129(17.5 \%)$ were since $2-3$ years (T-3)

Out of all 39 tube ligated and 144 hystrectomy cases develop hypothyroid presentation within 1 year while majority of tube ligation (231) taken 2-3 years and hysterectomy (109) developed the presentation by $2^{\text {nd }}$ year while 6 patients tube ligation taken $>3$ years to develop (T-4)

As per biochemical status majority 367 (49.7\%) were with TSH 4.5-5.5,63(8.5\%) fasting blood sugar $>120 \mathrm{mg}$ and $27 \%$ with Post prandiol blood sugar $>160 \mathrm{mg} \%$ though 7 cases were with pp blood sugar $>240 \mathrm{mg} \%, 2.3 \%$ shows altered hepatic, $2 \%$ with altered renal while $16.8 \%$ show marked anemia (T-5)

324 patients were taking Levo thyroxin supplementation in increasing dose without clinical relief and 414 were patients with presentation of hypothyroidism without any drug supplement (T-6, Bar diagram)

Post therapy assessment show complete alleviation of presenting feature with grade I clinical response in 367 of trial group patients while non of control group. In addition majority of trial group achieved hemato hepato renal normalcy (T-7)

\section{DisCUSSION}

Incidence of hypothyroidic manifestation is increasing progressively among female specially undergoing Tube ligation or hysterectomy and trend of therapy is Levo thyroxin supplimenation usually when TSH value $>5.5$ but patients remain in agony of hypothyroidic manifestation even when TSH is in between 1.5-5.5,In addition usually patients on Levo thyroxin supplementation fails to show positive response even on increasing dose, may be due to un regulated thyroxin synthesis, release and utilization through its hormone axis.
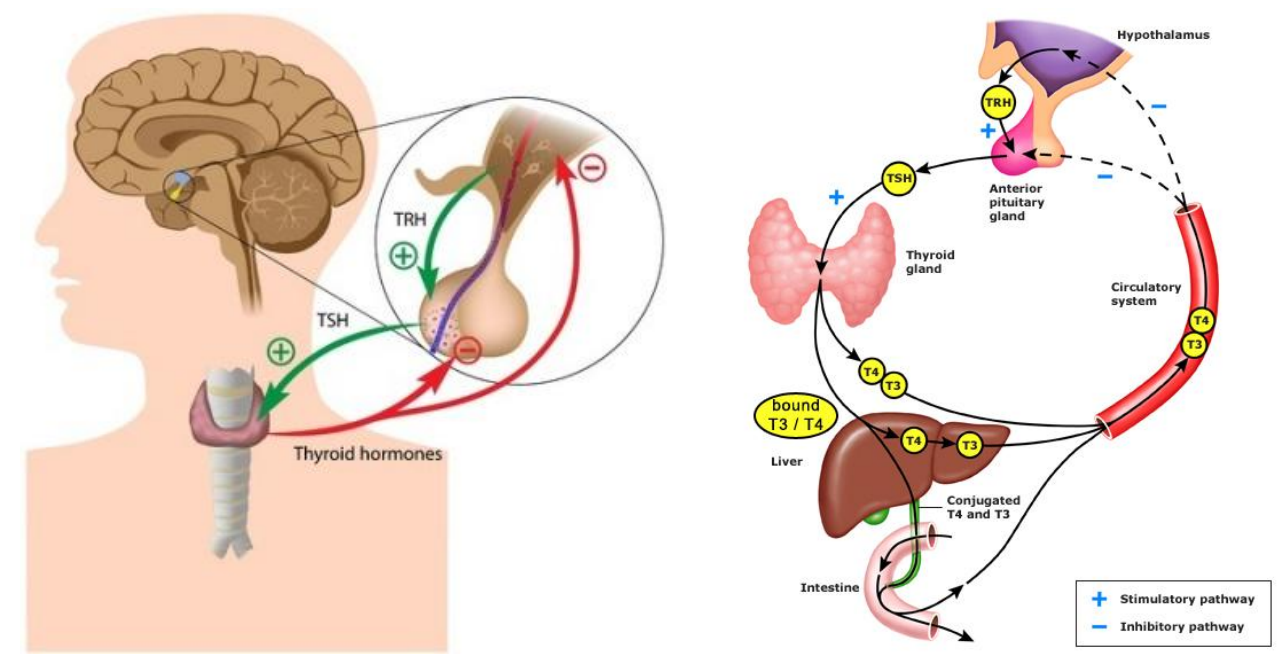
Thus with due education regarding Levo thyroxin supplementation, Calcium Gluconate intravenous every $15^{\text {th }}$ day, Cholecalciferol every week and Thyro Reg 1 Capsule daily in trial group ,patient had complete relief of the presenting feature with normalcy in vital and biological values as -Active constituent of Thyro-Reg bioregulate thyroid function i.e.- secretion of follicular and parafollicular cells i.e.- Thyroxin and Calcitonin and its release by activating Thyroid releasing factor ,in addition immune improving property vigorate both cells of thyroid gland. Supplimentation of Calcium gluconate intravenously ensure availability of ionic calcium and cholecalciferol facilitatae utilization of Calcium ensuring better neuro conduction and relieves neuropathic manifestation and dyspnea due to improved cardiac contractility.

Active constituent of Bauhinia varigata (bark) promotes conversion of Tyrosine to Thyroxin ,by potentiating the enzyme tyrosinase, Herpestis monnieri stimulate hormone axis (THP) and increases TRF ${ }^{13,14,15,16,17,18,19}$, Hepato stimulant Phyllanthus emblica, Terminalia chebula, Terminalia bellerica promotes active conversion of Cholecalciferol to Calcitrol facilitate optimum calcium concentration to maintain and bioregulate neuro cardiac and muscular activity. In addition immune improving character of Phyllanthus emblica,

Active ingradients of Zingiber officinale,Piper longum and Piper nigrum acting as anti inflammatory and stimulant to thyroid pituitary axis promotes thyroid tissue regeneration and bioregulation of thyroid activity . Crataeva nurvala active ingradient also synergizes with its anti inflammatory activity and bioregulate calcium metabolism and ensure ionic calcium concentration in body fluids.

Elettaria cardamom, Cinnamomum zeylanica and Cinnamomum tamla ensure conversion of tyrosine to thyroxin, and Herrpestis monnieri improves neural function and acting both on CNS and PNS alleviate presentation of neuropathy, ensuring bioregulated thyroid function ${ }^{20,21,22}$

\section{CONCLUSION}

Trial group both fresh cases of hypothyroidism after tube ligation or hysterectomy and hypothyroid patients taking levothyroxin supplement with persistiting manifestation shows grade I clinical response against non of control group. Control group shows symptomatic relief but not complete alleviation (grade II)

No patients of either group shows drug related adversity or exacerbation of presenting features.

Table1. Shows age and clinical status wise distribution of patients

\begin{tabular}{|l|l|l|l|}
\hline Age group (in yrs) & \multicolumn{3}{|c|}{ Number of patients } \\
\hline & Tube ligation & Hystrectomy & Total \\
\hline$<25$ & 07 & - & 07 \\
\hline $25-30$ & 79 & 17 & 96 \\
\hline $30-35$ & 88 & 29 & 117 \\
\hline $35-40$ & 127 & 56 & 183 \\
\hline $40-45$ & 92 & 70 & 162 \\
\hline$>45$ & 81 & 92 & 173 \\
\hline
\end{tabular}

Pie diagram showing distribution of patients as per clinical state

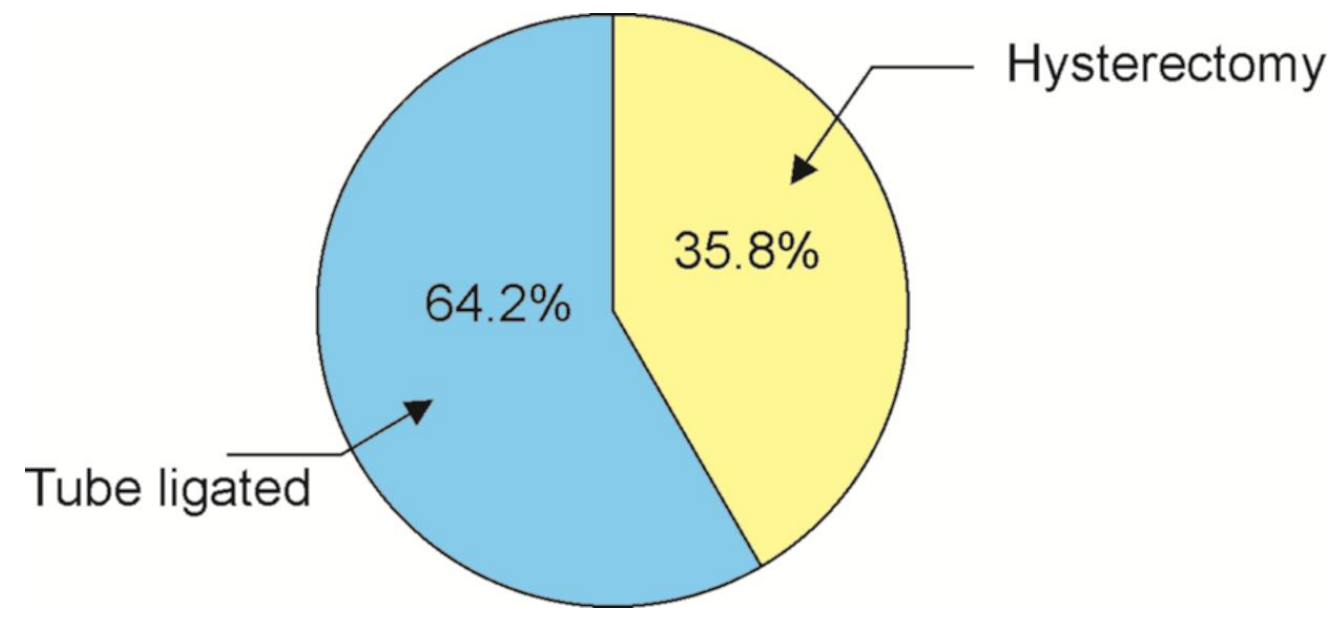


Table2. Distribution of patients as per clinical presentation

\begin{tabular}{|l|l|l|l|l|l|l|}
\hline Particulars & \multicolumn{7}{|c|}{ Number of patients } \\
\hline Age in yrs---- $\rightarrow$ & $<25$ & $25-30$ & $30-35$ & $35-40$ & $40-45$ & $>45$ \\
\hline Heaviness in the body & 07 & 96 & 117 & 183 & 162 & 173 \\
\hline Heaviness in the abdomen & 07 & 96 & 117 & 183 & 162 & 173 \\
\hline Progressive weight gain & 07 & 96 & 117 & 183 & 162 & 173 \\
\hline Exertional dyspnoea & 06 & 96 & 117 & 183 & 162 & 173 \\
\hline Vertigo & 06 & 90 & 110 & 181 & 162 & 173 \\
\hline Lethargy & 07 & 96 & 117 & 183 & 162 & 173 \\
\hline Constipation & 07 & 96 & 117 & 183 & 162 & 173 \\
\hline Scanty menses & 07 & 67 & 109 & 143 & - & - \\
\hline Tingling and numbness & 07 & 96 & 117 & 183 & 162 & 173 \\
\hline Leg cramp & 07 & 96 & 117 & 183 & 162 & 173 \\
\hline Palpitation & 06 & 90 & 110 & 180 & 162 & 173 \\
\hline Pain in multiple joints & 05 & 95 & 56 & 83 & 100 & 148 \\
\hline
\end{tabular}

Table3. Distribution of patients as per duration of presentations

\begin{tabular}{|l|l|l|l|l|l|l|l|}
\hline Duration in yrs & \multicolumn{9}{|c|}{ Number of patients } \\
\hline Age group ----- $\rightarrow$ & $<25$ & $25-30$ & $30-35$ & $35-40$ & $40-45$ & $>45$ & Total \\
\hline$<1$ & 04 & 09 & 09 & 29 & 11 & - & 62 \\
\hline $1-2$ & 03 & 32 & 20 & 17 & 14 & - & 86 \\
\hline $2-3$ & - & 23 & 30 & 43 & 17 & 16 & 129 \\
\hline $3-4$ & - & 18 & 21 & 23 & 24 & 16 & 102 \\
\hline $4-5$ & - & 09 & 14 & 13 & 20 & 19 & 75 \\
\hline $5-6$ & - & 05 & 09 & 19 & 11 & 24 & 68 \\
\hline $6-7$ & - & - & 04 & 24 & 09 & 18 & 55 \\
\hline $7-8$ & - & - & - & 10 & 06 & 21 & 37 \\
\hline $8-9$ & - & - & - & 05 & 04 & 20 & 29 \\
\hline $9-10$ & - & - & - & - & 36 & 22 & 58 \\
\hline$>10$ & - & - & - & - & 10 & 17 & 27 \\
\hline
\end{tabular}

Table4. Group wise distribution of patients as per their clinical stage

\begin{tabular}{|l|l|l|l|}
\hline \multirow{2}{*}{ Clinical stage } & Number of patients & Total \\
\cline { 2 - 4 } & Group A & Group B & 246 \\
\hline Stage I & 143 & 143 & 324 \\
\hline Stage II & 162 & 162 & 124 \\
\hline Stage III & 062 & 062 & \\
\hline
\end{tabular}

Table5. Distribution of patients as per their basic bio parameters

\begin{tabular}{|l|l|}
\hline Bio parameters & Number of patients \\
\hline Thyroid stimulating Hormone(TSH): & \\
\hline $0.5-1.5$ & - \\
\hline $1.5-2.5$ & 19 \\
\hline $2.5-3.5$ & 119 \\
\hline $3.5-4.5$ & 233 \\
\hline $4.5-5.5$ & 367 \\
\hline Blood Sugar(mg\%): & \\
Fasting - & 07 \\
\hline$<70$ & 62 \\
\hline $70-80$ & 56 \\
\hline $80-90$ & 415 \\
\hline $90-100$ & 76 \\
\hline $100-110$ & 59 \\
\hline $110-120$ & 63 \\
\hline$>120$ & \\
\hline Post prandial : & 70 \\
\hline$<120$ & 329 \\
\hline $120-140$ & 140 \\
\hline $140-160$ & \\
\hline
\end{tabular}


Hypothyroidism and Ayurveda

\begin{tabular}{|l|l|}
\hline \multicolumn{2}{|l|}{} \\
\hline $160-180$ & 71 \\
\hline $180-200$ & 38 \\
\hline $200-220$ & 63 \\
\hline $220-240$ & 20 \\
\hline$>240$ & 07 \\
\hline Renal parameters: & \\
Blood urea (mg\%): & 721 \\
\hline$<30$ & 17 \\
\hline$>30$ & \\
\hline Serum creatinine(mg\%) & 724 \\
\hline$<1.5$ & 14 \\
\hline$>1.5$ & \\
\hline Heaptic parameter (IU): & 732 \\
\hline SGOT: & 06 \\
\hline$<35$ & \\
\hline$>35$ & 732 \\
\hline SGPT: & 06 \\
\hline$<30$ & \\
\hline$>30$ & 124 \\
\hline Hematological (gm\%): & 614 \\
\hline$<10$ & \\
\hline$>10$ & \\
\hline
\end{tabular}

Table6. Shows lag period after tube ligation or hysterectomy

\begin{tabular}{|l|l|l|}
\hline Time period (in years) & Number of patients \\
\hline & Tube ligation & Hystrectomy \\
\hline$<1$ & 39 & 144 \\
\hline $1-2$ & 198 & 10 \\
\hline $2-3$ & 231 & 11 \\
\hline$>3$ & 06 & - \\
\hline
\end{tabular}

Table7. Showing outcome of therapy

\begin{tabular}{|c|c|c|}
\hline \multirow[t]{2}{*}{ Particulars } & \multicolumn{2}{|l|}{ Number of patients } \\
\hline & Group A (Trial group) & Group B (Control group) \\
\hline Complete clinical relief & 369 & 125 \\
\hline \multicolumn{3}{|l|}{ TSH level : } \\
\hline$<0.5$ & 28 & - \\
\hline $0 .-1$ & 341 & - \\
\hline $1-1.5$ & - & - \\
\hline $1.5-2$ & - & - \\
\hline $2-2.5$ & - & - \\
\hline $2.5-3$ & - & - \\
\hline $3-3.5$ & - & - \\
\hline $3.5-4$ & - & - \\
\hline $4-4.5$ & - & 21 \\
\hline $4.5-5$ & - & 31 \\
\hline $5-5.5$ & - & 71 \\
\hline$>5.5$ & - & 246 \\
\hline \multicolumn{3}{|l|}{$\begin{array}{l}\text { Blood Sugar(mg\%): } \\
\text { Fasting - }\end{array}$} \\
\hline$<100$ & 358 & 290 \\
\hline$>100$ & 11 & 79 \\
\hline \multicolumn{3}{|l|}{$\begin{array}{l}\text { Hepatic profile : } \\
\text { SGOT(IU): }\end{array}$} \\
\hline$<30$ & 369 & 366 \\
\hline$>30$ & - & 03 \\
\hline \multicolumn{3}{|l|}{ SGPT(IU): } \\
\hline$<30$ & 369 & 367 \\
\hline$>30$ & - & 05 \\
\hline
\end{tabular}




\begin{tabular}{|l|l|l|}
\hline $\begin{array}{l}\text { Renal profile(mg\%) : } \\
\text { Blood Urea }\end{array}$ & & \\
\hline$<30$ & 369 & 364 \\
\hline$>30$ & - & 05 \\
\hline Serum creatinine & & \\
\hline$<30$ & 369 & 365 \\
\hline$>30$ & - & 04 \\
\hline $\begin{array}{l}\text { Hematology (gm\%) } \\
\text { Hemoglobin : }\end{array}$ & & \\
\hline$<10$ & - & 105 \\
\hline$>10$ & 369 & 264 \\
\hline Clinical grading : & & \\
\hline Grade I & 367 & - \\
\hline Grade II & 02 & 240 \\
\hline Grade III & - & 129 \\
\hline
\end{tabular}

Table8. Bar diagram showing distribution of patients as per their therapeutic state

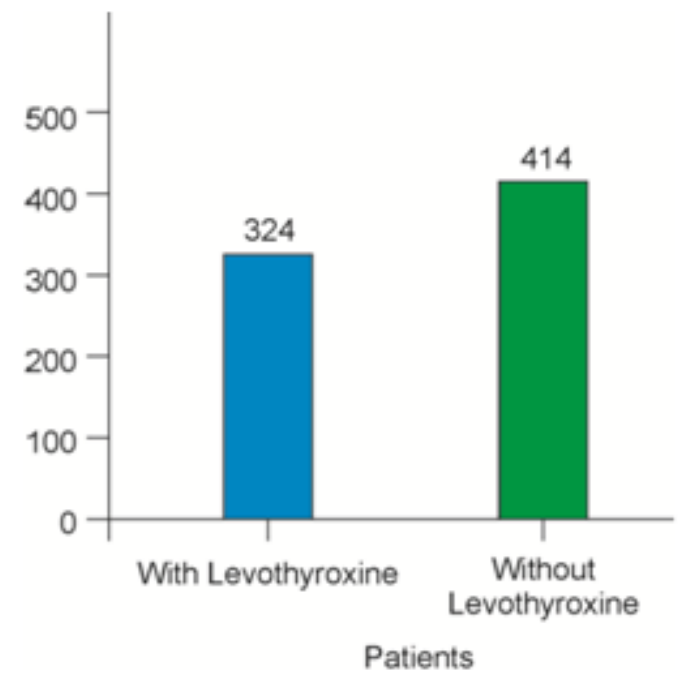

\section{REFERENCES}

[1] Ambika Gopalakrishnan Unnikrishnan and Usha V. Menon, Indian journal of Endocrinology \& Metabolism, 2011 Jul; 15 (Suppl2): S78-S81. doi: 10.4103/2230-8210.83329

[2] Thomas CPT, Francis MC. Common thyroid disorders in the elderly. Postgraduate Medicine. 1992; 92 (3): 225-30. [PubMed]

[3] Tunbridge W M, Evered D C, Hall R. et al The spectrum of thyroid disease in a community; the Whickham survey. Clin Endocrinol (Oxf) 19777481-493. [PubMed]

[4] Vanderpump M P, Tunbridge W M, French J M. et al The incidence of thyroid disorders in the community; a twenty year follow up of the Whickham survey. Clin Endocrinol (Oxf) 1995435568.[PubMed]

[5] Flynn R W V, MacDonald T M, Morris T M. et al The thyroid epidemiology, audit and research study: thyroid dysfunction in the general population. J Clin Endocrinol Metab 2004893879-3883. [PubMed]

[6] Kawther T. El-Shafie, MD Clinical presentation of hypothyroidism ,J Family Community Med. 2003 JanApr; 10(1): 55-5

[7] Baloch Z, Carayon P, Conte-Devolx B. et al Laboratory medicine practice guidelines; Laboratory support for the diagnosis and monitoring of thyroid disease. Thyroid 2003133-126. [PubMed]

[8] Gharib H, Tuttle M, Baskin J. et al Consensus statement: subclinical thyroid dysfunction: A joint statement on the management from the American Association of Clinical Endocrinologists, the American Thyroid Association and the Endocrine Society. J Clin Endocrinol Metab 200590581-586. [PubMed]

[9] Biondi B, Palmieri E A, Klain M. et al Subclinical hyperthyroidism; clinical features and treatment options. Eur J Endocrinol 20051521-9. [PubMed]

[10] Chopra I. Euthyroid sick syndrome: Is it a misnomer? J Clin Endocrinol Metab 199782329-334.[PubMed] 
[11] The American Thyroid Association, The Endocrine Society, American Association of Clinical Endocrinologists Joint statement on the US Food and Drug Administration's decision regarding bioequivalence of levothyroxine sodium. Thyroid 200414486 [PubMed]

[12] Walsh J P, Shiels L, Lim E M. et al Combined levothyroxine/liothyronine treatment does not improve well being, quality of life, or cognitive function compared to thyroxine alone: a randomised controlled trial in patients with primary hypothyroidism. J Clin Endocinol Metab 2003884543-4550. [PubMed]

[13] Mopuru VB Reddy, Muntha K Reddy, Gunasekar D, Caux C, Bodo B. A flavanone and a dihydrodibenzoxepin from Bauhinia variegate. Phytochemistry 2003; 64: 879-82.

[14] Yadava RN, Reddy VM. Anti-inflammatory activity of a novel flavonol glycoside from the Bauhinia variegata Linn. Nat Prod Res 2003; 17(3): 165-9.

[15] Mohamed MA, Mammoud MR, Hayen H. Evaluation of antinociceptive and anti-inflammatory activities of a new triterpene saponin from Bauhinia variegata leaves. Z Naturforsch C 2009; 64(11-12): 798-808.

[16] Zhao YY, Cui CB, Cai B, Han B, Sun QS. A new phenanthraquinone from the stems of Bauhinia variegata L. J Asian Nat Prod Res 2005; 7(6): 835-38.

[17] Rao YK, Fang SH, Tzeng YM. Antiinflammatory activities of flavonoids and a triterpene caffeate isolated from Bauhinia variegata. Phytother Res 2008; 22(7): 957-62.

[18] Surendhra H, Bodakhe, Alpana ram. Hepatoprotective properties of Bauhinia variegata bark extract. Yakugaku Zasshi the pharma soc of jap 2007; 127(9):1507-9.

[19] Rajani GP, Ashok P. In vitro antioxidant and antihyperlipidemic activities of Bauhinia variegate Linn. Indian J Pharma col 2009; 41(5):227-32.

[20] Gruenwald J, Freder J, Armbruester N. Cinnamon and health. Crit Rev Food Sci Nutr. 2010; 50:822-834. doi: 10.1080/10408390902773052. [PubMed] [Cross Ref]

[21] Paranagama PA, Wimalasena S, Jayatilake GS, Jayawardena AL, Senanayake UM, Mubarak AM. A comparison of essential oil constituents of bark, leaf root and fruit of cinnamon (cinnamomum zeylanicum Blum), grown in Sri Lanka. J Natl Sci Found Sri. 2010; 29:147-153.

[22] Archer A. Determination of cinnamaldehyde, coumarin and cinnamyl alcohol in cinnamon and cassia by high-performance liquid chromatography. J Chromatogr. 1988; 447:272-276.

Citation: A. Shankar et al., "Hypothyroidism and Ayurveda", International Journal of Clinical Chemistry and Laboratory Medicine (IJCCLM), vol. 3, no. 3, pp. 8-15, 2017. http://dx.doi.org/10.20431/2455-7153.0303002

Copyright: (C) 2017 Authors. This is an open-access article distributed under the terms of the Creative Commons Attribution License, which permits unrestricted use, distribution, and reproduction in any medium, provided the original author and source are credited. 